\title{
ASIAN RELIGIONS AS RESOURCES FOR CHANGING MINDSETS
}

\author{
Goh Beng Lan \\ Department of Area Studies, Faculty of Humanities, Universitas Indonesia \\ $<$ Benglan@gmail.com>
}

\begin{abstract}
This paper argues that Asian religious traditions provide us with resources for alternative ethics and methodologies of resisting capitalist excesses and social-cultural intolerances towards more convivial and viable human futures. It draws inspiration from two major developments. First, the works of Prasenjit Duara (2015) and Joel S. Kahn (2015) that posit Asian religious traditions as resources for generating alternative ethics as well as contemplative and embodied ways of knowing that direct self and collective capacities to overcome environmental sustainability and social-cultural incompatibilities. Second, everyday politics of resisting religious bigotries in contemporary Malaysia that turn to spiritual traditions for mindful ways of minimizing, bridging or transcending irreducible ethno-religious differences.
\end{abstract}

\section{Introduction}

In recent times, spiritual truth claims of Asian religions have become subject of interests to scholars as possible resources to solve worldly problems today such as capitalist excesses, cultural intolerance and environmental unsustainability. Academic interests have revolved centrally around claims of alternative logics and methods of knowing offered by Asian religions that differ from classical Western dichotomous thought and scientific epistemologies. In this paper I want to consider the relevance of Asian religions as resources for changing mindsets as the basis of new progressive politics for human betterment in an era of cultural conflicts and environmental destruction. I will make my arguments in two steps. First, I will draw on two recent studies that locate Asian religions as resources for reformulating self and community for human betterment as the basis for rethinking mindset change as a basis 
for radical politics. Here, I am inspired by Prasenjit Duara's The Crisis of Global Modernity and Joel S Kahn's Asia, Modernity and the Pursuit of the Sacred: Gnostics, Scholars, Mystics and Reformers (2015). Second, I will draw on my own research on resistance against ethno-religious bigotries in contemporary Malaysia that turn to spiritual traditions for creative resolutions of minimizing and/ or transcending incompatible ethnoreligious differences.

\section{Recent Rethinking of Asian Religious Traditions}

In a recent work addressing the crisis of global modernity, Prasenjit Duara, a historian, points to Asian religions as promising resources for overcoming the threat of planetary destruction. Turning to axial age debates, ${ }^{1}$ Duara recovers Asian religious traditions as resources for growing the seeds of resistance against the materialism and consumerism of our time. Religious traditions, he argues, have long served as forms of "non-worldly moral authority" outside of state powers to overcome domination across time in Asia (Duara 2015, 4, his emphases). In face with growing materialism and consumerism that have put the world at risk of

1 Axial Age debates refer to an era of human mastery over nature prior to Western European and EuroAmerican modernity whereby spiritual truthclaims were used to solve worldly problems across China, India, the Middle East, and Greece around 800200BCE (Eisenstadt 1999). destruction, Asian religious traditions provide us with promising resources for growing the seeds of resistance against environmental unsustainability. Duara argues that the region's traditions such as Confucianism, Hinduism, Buddhism, Daoism, folk religions, redemptive societies, and other faithbased cosmologies have long inspired the "discipline of self-formation or selfcultivation and the methodologies of linking the self to locality, community, environment and the universal" (ibid, 2 ). He argues that both state/elites and ordinary Asians have drawn on moral authority from these non-worldly traditions to overcome unruly and/ or oppressive forces in the past and present. He suggests that such moral authority "serves as a historical motor to empower the quest of justice and its ideal of a better world" (ibid, 125). Such ethics represent a form of "dialogical transcendence" or "a way of human knowing based upon an inscrutable yearning or calling with several attributes that coexist in varying degrees" (ibid, 6, his emphases). Taking the transcendent as "an inviolable (moral) moral space that may not be fundamentally religious but may be a condition for human aspirations", Duara sees dialogical transcendence as a method through which groups accommodate diversity through techniques of self-formation that involve bodily practices and embodied knowing (ibid, 125). Importantly, this 
ethic of dialogical transcendence is not only a religious inspiration but plays a historical role in the moral empowerment of opposition against injustices and renewals of Asian societies.

Building on the circulatory flow of history, where ideas spread from one location to another only to return to their original source, Duara argues that the contemporary crisis of environmental unsustainability provides conditions of possibility for the re-emergence of Asian practices of dialogical transcendence. Asian religious traditions, he argues, can renew and rescue human societies from the threat of destruction. The radical promise of dialogical transcendence lies in its ethic of accommodating diversity. According to Duara, "dialogical transcendence" is "a way of human knowing based upon an inscrutable yearning or calling with several attributes that coexist in varying degrees" (ibid, 6, his emphases). This ethic, he argues, arises from the region's religious traditions such as Confucianism, Hinduism, Buddhism, Daoism, folk religions and other faith-based cosmologies that have long inspired the "discipline of self-formation or self-cultivation and the methodologies of linking the self to locality, community, environment and the universal" (ibid, 2). There is a physical aspect to attaining this spiritual ethic. Dialogical transcendence is accessed via bodily practices whereby the body is "both the map and the means of salvation" (ibid, 150).

To substantiate the force of dialogical transcendence in transforming and renewing Asian societies across time, Duara refers to a variety of historical and contemporary examples. Among these he includes redemptive societies, regional spiritual environmental movements, such as forest monks in Thailand and Cambodia, the transnational Taiwanese Buddhist Compassion Relief Tzuchi Foundation, and an assortment of nongovernmental organizations (NGOs) and environmental nongovernmental organizations (ENGOs) engaged in sustainability efforts to salvage the world from destruction.

All in all, the ethical tradition of "dialogical transcendence" argued by Duara carries an alternative logic whereby power and change are not mutually exclusive, static or hierarchical. Such a logic bears promise for providing a "third" way of reconciling radical differences whereby continuity and change, the universal and the particular, and the inside and outside need not cancel each other out but co-exist in fusion, complementarity and instantaneity. For Duara, it is the principle of dialogical transcendence that directs self and collective moral responsibility towards the achievement of ecological equilibrium. It is one that imbricates diverse human, material, and spiritual forces. 
Duara also argues that embodied or experiential knowing is part and parcel of Asian religious traditions. In contrast to abstract knowing, embodied or experiential learning posits the body as a powerful vessel of knowledge transmission through which discipline, immersion, ritual participation, and other bodily practices are important mediums that bridge the worldly and non-worldly to enable transcendent ethical inculcation (Duara 2015, 149155).

Duara is not alone in seeing potential in Asian religious traditions. Such a view is shared by anthropologist Joel S. Kahn whose work has focused much on Islamic societies of Malaysia and Indonesia. In his last work, Asia, Modernity and the Pursuit of the Sacred: Gnostics, Scholars, Mystics and Reformers (2015), ${ }^{2}$ Kahn equally looks at religious traditions as cultural and intellectual resources for bridging and transcending incompatible differences. In this work, Kahn seeks to understand Indonesian Sufi ideas and methodologies of knowing the sacred. As an outsider to Islam, Kahn's way of understanding Indonesian Sufism is to find cultural/intellectual resources within his own Western traditions to access Sufism. For this, he turns to interwar Western Gnosticism as an intellectual-cumcultural resource for him to understand Sufism. In doing so, Kahn charts a

2 Kahn passed away in 2017. new course of bring together ideas and methods of knowing together in Western Gnosticism and Indonesian Sufism so as to understand how each of these religious traditions approach the "sacred". The conversations forged between Gnosticism and Sufism open up a multiplicity of viewpoints, shedding light on correspondences as well as unexpected interlinkages across seemingly incommensurable difference.

Kahn's effort to bring Indonesian Sufism and interwar Gnosticism into comparison shows the possibility for all cultures/societies to find resources within their own cultural and intellectual backgrounds to grasp otherness/differences. To Kahn, interwar Gnosticism provides an example of an inter-religious project that is situated in both Western worldviews as well as Asian ones whereby the knowledge produced speaks of and to both the worlds of the researcher and the studied. Kahn argues that the experiential and contemplative methodologies adopted by both Gnostics and Sufis are promising in facilitating cross-religious understanding and embracement. Kahn shows how Gnostic and Sufi ways of knowing-which are at once ideational and practical-stand in contrast to abstract reasoning in the social sciences. Central to Sufi and Gnostic styles of knowing is the aspect of experiential and embodied learning as one intentionally seeks to enter into "unseen" or even "impossible" worlds 
in order to bring about encounters and understandings of the "sacred" from within the self as well as for the self to become at one with such unseen or unknown worlds. Kahn shows how embodied and contemplative knowing facilitates one to step into totally alien forms of metaphysical and ontological claims. Such embodied knowing brings about an ability to see different ideational and ontological worlds as complementary to one another in contrast to narrow dualistic Western Enlightenment thinking

They provide us with an alternative logic of the complementarity of differences whereby different ideational and ontological worlds are seen to be mutually constitutive and interrelated, offering a completely contrasting logic to narrow, dualistic Western Enlightenment thinking. Far from apolitical, Kahn argues that such sacred forms of knowing are characterized by the quest for openness, responsibility for others, non-violence, and respect for the natural world -ideas which are much needed in the contemporary world.

The distinctive set of strategies adopted by Duara and Kahn to insist on religious traditions as resources for enabling alternative thought and action to see and forge interlinkages across seeming incommensurable differences, is a useful one. From my own research, I have discovered that everyday resistance in face of a deeply bifurcated public sphere over rising Islamic conservatism in recent Malaysia has equally drawn inspiration from religious alterities to pursue translatability across incompatible differences

\section{Theoretical Possibilities from Southeast Asia? Ethical Traditions as Resistance}

A quick survey of a sub-region of Southeast Asia, namely Indonesia and Malaysia, points to a similar turn to practices of spiritual and cultural traditions and, I would add, even simple human compassion. In these two Muslim-dominated, yet plural societies, resistance is growing against narrow varieties of Islamic orthodoxies that have created deeply bifurcated civil societies. In response to an incapacitated, highly charged public sphere, political critiques have turned to new subterranean and everyday spaces. They take the form of a quiet spread of alternative Islamic imaginaries not in accord with dominant conceptions. For instance, there has been a revivalism of Sufism - a mystical practice emphasizing personal, humanistic, fluid, and compassionate dimensions of Islam, as resistance against the growing strains of dominant Islam in these countries (e.g., see Fauzi Abdul Hamid 1999). In a previous study, I showed how an urban revival of a local Muslim guardian spirit, the keramat, which incorporates a syncretic mixture of Islam, Hindu-Buddhist, Sinic, and 
animistic cosmologies, defies the orthodoxy of mainstream religious definitions and offers a further example of spiritual resistance (Goh 2012).

More recently, my research has focused on creative resistance in artistic practices and grassroots initiatives by private citizens in Malaysia. Case studies include artistic practices and cyber networks perpetuating urban keramat (Muslim guardian saints), ${ }^{3}$ Sufism and alternative religious communes, such as Kerajaan Langit (Sky Kingdom). ${ }^{4}$ The articulation of basic human decency and compassion is especially visible in the artistic satire of puritanical Islamic hypervigilance of the body, social conduct, and religious morals as portrayed, for example, in Malaysian contemporary art and street art. Similarly, it is observed in the practices of a variety of civil initiatives that include interfaith dialogues and events. One such event was the "I Want to Touch a Dog" event at an urban park outside Kuala Lumpur in 2014

3 Keramat is a syncretic Muslim guardian saint cult with deep roots in the Malay world that combines Indian-derived Shia' beliefs, Sufi mysticism (tasauf), and Malay animistic notions of souls (semangat).

4 Sky Kingdom, a cult that promoted universal unity among all religions by drawing on a mixture of Hindu, Buddhist and Christian cosmologies, had its beginnings in the 1980s but was destroyed by the Malaysian state in 2005. Fantastic symbolisms and hagiography around its mysterious, now deceased, spiritual leader, have kept this cult alive in Malaysian public and cyber imaginings. There are at least four Wikipedia entries (in English and Malay) and many virtual sites about this cult. There is even an Australian SBS TV documentary on Sky Kingdom. http://www.sayaanakbangsamalaysia. net/index.php?option=com_content $\&$ view=artic le\&id=69: background-to-sabm\&catid=43:sabminitiative \& Itemid $=56$ in response to the arrest of a Muslim dog trainer for "wounding religious feelings" after a video of her bathing her dogs (proscribed animals in Islam) circulated on Facebook.

Other examples are citizenry initiatives that appears to re-inscribe new national mind-sets in the context of rising ethno-religious conflicts in the new millennium by turning to institutional, historical and spatial resources to recover intercultural imaginations so as to break down the walls of ethno-religious differences and create new convivial possibilities. One case is the Saya Anak Bangsa Malaysia (SABM) which seeks to foster inter-ethno-religious dialogue and instil the spirit of "One People, One Nation" in Malaysia in combating ethno-religious fanaticism. SABM is a loose coalition of "like-minded" people which was established in 2007 in response to a passionate article written by a young Malaysian, entitled, "Break the shackles of "Tribal Think" posted in a popular Malaysian blog which sparked off earnest discussions over the internet. This loose coalition is not the usual social movement. It has both virtual and real presence. It has a Charter - and amongst its commitments are: "a) to Engender a National Mindset to think and act first and foremost as Malaysians; and b) to engage the Hearts and Minds of our people to rise above the social constructs and divisive forces of ethnicity, faith, 
colour, class or gender." Its website invites contributions, opinions and photos from ordinary Malaysians on everyday history, stories of past, present and future and in the process builds up an archive of alternative Malaysian narratives on social life, history, outlooks on ethnicity and religion and so on. Membership is loose if not ambiguous, and members are described on its website as:

"...citizen volunteers, commoners, faceless perhaps but not spineless. We are non-partisan. We come from diverse backgrounds, we have different temperaments, different shapes and sizes and we are of different ages. Different, yet the same no less."

Clearly the intercultural ideals of this coalition are its force. This coalition is kept alive as "members" organize Saya Anak Bangsa Malaysia Neighborhood Get-togethers. To date, SABM has chapters in the majority of Malaysian cities and with an overseas chapter in Melbourne, Australia. One of their projects is the "One People, One Nation" Country Wide Road-Show, launched in 2009, to promote interfaith dialogue and discussions over the Malaysian Federal Constitution.

Indeed for the inaugural launch of this roadshow, SABM used a little known but significant historical building located in Georgetown, Penang, The Hu Yew Seah, or literally the "League of Helping Friends" (see Goh 2013). Hu Yew Seah is a cultural literary Association established 1914 during an era of cosmopolitanism and transnationalism in (Southeast) Asia that has been noted by Joel as well as various other scholars (for example, see Kahn 2006, Shiraisi 1990, Siegel 1997, Harper and Amrith 2012). The choice to use the $\mathrm{Hu}$ Yew Seah as the launching pad was no accident as this club has an inspirational social-cultural history not commonly known to Malaysians. While the Hu Yew Seah is only known today by a sleek and minimalist elegant building associated with the Art Décor Style that stands in the heart of Georgetown, Penang, this Association has a history that is charged with inspirational inter-cultural imaginings. To many younger Malaysians, the $\mathrm{Hu}$ Yew Seah is no more than a recreational club for its members. Indeed, a visit to the building today tells little about its glorious history. However, a small marble plaque mounted on a wall in the main hall of the building provides a clue to its splendid past. The plaque marks the foundational stone laid by Nobel laureate poet and philosopher Rabrindranath Tagore who inaugurated the building on 14 August, 1927 (Hu Yew Seah 1966: 17). This plaque is a tell-tale sign of Hu Yew Seah's status as cultural-literary Association at the forefront of social-cultural life in Penang during the early decades of 1920s.

While seemingly disparate, these occurrences are united by a rejection of ethno-religious dogmas and use of 
a particular mode of protest. These protests combine social media and reclamations of alternative spiritual, moral, and humane traditions via a play of form and images. These configurations involve curious "political" actors and alliances: property developers and petty entrepreneurs, urban dwellers, religious leaders and followers, artists and concerned citizens. Occurring away from a highly charged public sphere, these innovations stimulate new and open ways of interrogating, expressing, blurring, and minimizing ethno-religious differences. Importantly, their alternative ethnoreligious representations - which are either directly expressed in or find their way into cyber networks - strike powerful cords with, and are easily understood by, fellow Malaysians who are cognizant of these humane, less judgmental, more tolerant and fluid understandings of Islam with historical roots in the Southeast Asian region.

These everyday pursuits of intercultural logics and creative modes seeking to transcend and rethink ethnoreligious differences in Malaysia provide us with grounds to understand the generation of dialogical spaces that open new understandings of mutuality and interdependence. They suggest that in a society where ethno-religious bigotries have invaded private identities and eradicated meaningful public debate the seeds of revolutionary change may have to first take root in people's everyday mindful self-transformations and the convivial spaces generated.

\section{Conclusion}

In this paper I have shown how Asian religious traditions may serve as important resources to inspire creative resistance for a better world at a time when the world is heading into unchartered waters of socialpolitical and cultural transformations and conflicts. Practices of religious traditions may not fit easily into what social scientists would usually consider as politics. Nonetheless, they offer hope of alternative political aspirations and human conviviality other than the political extremes found in the contemporary world. Nonbinary thinking as well as convivial and tolerant worldviews implicit in Asian religious worldviews suggest that radical change may lie in ordinary, everyday ways of practicing the principles of religious traditions and not merely in self-consciously political movements. Practicing religious values, a seemingly conservative category, becomes a source for revolutionary possibilities. While reclamations of religious ethics may not add up to a clear category of values or specific set of principles, it is possible to identify a rough approximation of prioritized values. These values bring into audibility and visibility neglected, if not silenced, imaginaries of conviviality and tolerance long in 
regional circulation which help us rediscover inter-connections, interdependence and mutual constitutions of life, people and ways of living in contrast to the narrowness and rigidness of current cultural identity discourses in the world. The reclamations and representations of religious traditions show that radical change begins with mindful transformations and that the material world, bodily experiences and performances are powerful conduits for the inculcation of ethical politics and action.[]

\section{References}

Ahmad Fauzi Abdul Hamid (1999) New Trends of Islamic Resurgence in Contemporary Malaysia: Sufi-Revivalism, Messianism and Economic Activism. Studia Islamika: Indonesian Journal for Islamic Studies 6 (3): 1-74.

Duara, Prasenjit (2015) The Crisis of Global Modernity: Asian Traditions and a Sustainable Future. United Kingdom: Cambridge University Press.

Eisenstadt S.N. (1999) Multiple Modernities in an Age of Globalization. Canadian Journal of Sociology 24(2): 283-95.

Goh Beng-Lan (2012) Spirit Cults and Construction Sites: Trans-ethnic Popular Religion and Keramat Symbolism in Contemporary Malaysia. In: Kirsten W. Endres and Andrea Lauser (eds) Spirited Modernities. Oxford: Berghahn Books, pp. 144-162.

(2013) Heritage as Knowledge: Time, Space, and Culture in Penang. In: Francis E. Hitchinson and Johan Saravanamuttu (eds) Catching the Wind: Penang in a Rising Asia. Penang Institute and ISEAS: Singapore, Pp. 42-54.

Harper, Tim and Amrith, Sunil S (2012) Sites of Asian Interaction: An introduction, Modern Asian Studies 46, 2: 249-257.

Hu Yew Seah (1966) Hu Yew Seah 50th Anniversary Magazine 1914-1964. Penang: Cathay Printers Ltd.

Kahn, Joel S (2015) Asia, Modernity and the Pursuit of the Sacred: Gnostics, Scholars, Mystics and Reformers. New York: PalgraveMacmillan.

(2006) Other Malays: Nationalism and Cosmopolitanism in the Modern Malay World. Singapore: Asian Studies Association of Australia in association with Singapore University Press and NIAS Press (Copenhagen). (Published in the United States by University of Hawaii Press).

Shiraishi, Takashi (1990) An Age in Motion: Popular Radicalism in Java, 1912-1926. Ithaca: Cornell University Press.

Siegel, James T (1997) Fetish, Recognition, Revolution. Princeton: New Jersey: Princeton University Press. 